\title{
ALPHA-AMYLASE AND ALPHA-GLUCOSIDASE INHIBITORY EFFECTS OF CALLIANDRA HAEMATOCEPHALA AND ITS POTENTIAL ROLE IN DIABETES MELLITUS
}

\author{
PUNNAGAI K ${ }^{1}$, GLORY JOSEPHINE I ${ }^{2 *}$ \\ ${ }^{1}$ Department of Pharmacology, Sri Ramachandra Medical College and Research Institute, Chennai, Tamil Nadu, India. ${ }^{2}$ Department of \\ Pharmacology, Sree Balaji Medical College and Hospital, Chennai, Tamil Nadu, India. Email: dr.gloryj@gmail.com
}

Received: 21 May 2018, Revised and Accepted: 20 August 2018

\begin{abstract}
Objective: The global burden and the high prevalence of diabetes mellitus in India signify the importance of its control with effective measures. Particularly, intestinal alpha-amylase and alpha-glucosidase enzyme inhibitors reduce postprandial hyperglycemia and play a key role in preventing diabetic complications. Herbal plants also possess greater antioxidant, enzyme inhibitory, and antihyperglycemic activities with minimal side effects. Hence, this study is done to elucidate the inhibition of alpha-amylase and alpha-glucosidase enzyme activity and antidiabetic potential of Calliandra haematocephala.
\end{abstract}

Methods: The leaves of $C$. haematocephala extracted by ethanol as a solvent were used to elucidate the blocking of alpha-amylase and alpha-glucosidase enzymes for antidiabetic effect, and the absorbance was measured using spectrophotometry. The percentage of inhibition and half maximal inhibitory concentration (IC50) value of the plant and control were calculated.

Results: The maximum percentage inhibition of $C$. haematocephala against alpha-amylase was $61 \%$ (IC50 value of $82.18 \mu \mathrm{g} / \mathrm{ml}$ ) and alpha-glucosidase was $71 \%$ (31.07 $\mu \mathrm{g} / \mathrm{ml}$ ). The maximum percentage inhibition of acarbose against alpha-amylase was $92 \%$ (IC50 value of $42.65 \mu \mathrm{g} / \mathrm{ml}$ ) and alphaglucosidase was $89 \%(62.28 \mu \mathrm{g} / \mathrm{ml})$.

Conclusion: Hence, the above study proved the antidiabetic activity of $C$. haematocephala and its significant role in the pharmacotherapy of diabetes mellitus.

Keywords: Calliandra haematocephala, Alpha-amylase, Alpha-glucosidase.

(C) 2018 The Authors. Published by Innovare Academic Sciences Pvt Ltd. This is an open access article under the CC BY license (http://creativecommons. org/licenses/by/4. 0/) DOI: http://dx.doi.org/10.22159/ajpcr.2018.v11i12.28517

\section{INTRODUCTION}

Diabetes mellitus presents with uncontrolled blood sugar levels due to lack of insulin or insulin resistance. For the past three decades, global prevalence of diabetes has almost doubled in the adult population, particularly in lower to middle socioeconomic group [1]. Hence, it is considered to be one of the four priority non-communicable diseases which are targeted for action. India shares the global diabetes burden because of early onset of disease, low awareness, and lifestyle modification [2]. Studies revealed the high prevalence of prediabetic state and rapid conversion of impaired glucose tolerance to diabetes in both South Indian urban and rural population [3]. Hence, the primary prevention and management are important because of rapid rise of vascular complications. Medicinal plants possess antidiabetic effect are used worldwide. They are effective in controlling plasma blood sugar and have minimal side effects. Considering the side effects of the antihyperglycemic drugs today, these plants could be a potential alternative or add-on drug and also reduce the economic burden. Moreover, the various chemical constituents target on different modes of mechanisms favor the treatment and prevention of complications $[4,5]$.

The plant Calliandra haematocephala (red powder puff) is an evergreen deciduous and well-branched shrub with silky leaves. These shrubs are $10-15^{\prime}(3-4.6 \mathrm{~m})$ height and belong to the family Mimosaceae (Touchme-not family). Red powder puff has attractive soft round brushes shaped flowers which bloom from October to April. The plant has been used in traditional medicine because of its blood purifying, antiinflammatory, gastroprotective, hepatoprotective, immunomodulatory, and antiulcerogenic properties. The phytochemical investigations show the presence of tannins, flavonoids, and saponins which are responsible for these activities. Studies proved that betulinic acid is responsible for its antitumor, anti-HIV, anti-rotavirus activities, and gallic acid for antibacterial activity [6-11].

Alpha-amylase and alpha-glucosidase inhibitors are used for the drug therapy of diabetes mellitus by reducing postprandial hyperglycemia. Many plants possess significant alpha-amylase and alpha-glucosidase curbing potential depicted by protection of the crops by suppressing the digestion of carbohydrate and change the feeding pattern of insects [12]. Studies proved about the bioactivity of polyphenols in plants and its correlation with their antioxidant and hypoglycemic properties [13]. Synthetic inhibitors such as acarbose and miglitol cause so many gastrointestinal side effects. Hence, the plant-derived alpha-amylase and alpha-glucosidase inhibitors could be a vital target for type 2 diabetes mellitus with minimal side effects. The two enzymes alpha-amylase and alpha-glucosidase and their inhibition by the ethanol extract of the study plant $C$. haematocephala are the design we postulated as the aim of the study.

\section{METHODS}

The $C$. haematocephala leaves were obtained in and around Madipakkam area and certified by Prof. P. Jayaraman, from Plant Anatomy Research Centre of West Tambaram. (Reg No. PARC/2017/3442).

\section{Sample extraction}

Soxhlet apparatus was used to extract the powdered sample ( $25 \mathrm{~g}$ ) of the plant with ethanol used as a solvent. The extract was condensed under reduced pressure in rotary vacuum evaporator and stored at $4^{\circ} \mathrm{C}$. 
In vitro methods for antidiabetic activity

Determination of alpha-amylase inhibitory activity

The alpha-amylase inhibitory effects of the plant extracts were elucidated by the method of Rege and Chowdary, 2014 [14]. The assay mixture containing $200 \mu \mathrm{l}$ of sodium phosphate buffer, $20 \mu \mathrm{l}$ of enzyme, and $20 \mu \mathrm{l}$ of extract was incubated for $10 \mathrm{~min}$ at room temperature followed by the addition of $200 \mu$ of starch in all the tubes. The reaction was stopped with the addition of $400 \mu \mathrm{l}$ of DNS reagent and kept in the boiling water bath for $5 \mathrm{~min}$, cooled and diluted with $15 \mathrm{ml}$ of distilled water and absorbance of the control, and the samples were measured at $540 \mathrm{~nm}$. The control sample was devoid of the plant extract. The percentage inhibition was analyzed by the formula:

\section{Calculation}

Percentage inhibition (\%)=Absorption of the control-Absorption of the sample/Absorption of the control $\times 100$.

\section{Determination of alpha-glucosidase inhibitory activity}

Reaction mixture containing $50 \mu \mathrm{l}$ phosphate buffer, $10 \mu \mathrm{l}$ alphaglucosidase, and $20 \mu \mathrm{l}$ of varying concentrations of extracts was preincubated at $37^{\circ} \mathrm{C}$ for $15 \mathrm{~min}$. Then, $20 \mu \mathrm{l}$ p-nitrophenyl- $\alpha$-DGlucopyranoside was added as a substrate and incubated further at PNPG for $30 \mathrm{~min}$. The reaction was stopped by adding $50 \mu \mathrm{l}$ sodium carbonate. The yellow color produced was observed at $405 \mathrm{~nm}$. Each experiment was carried out along with appropriate blanks. Acarbose at various concentrations $(20-100 \mu \mathrm{l} / \mathrm{ml})$ was included as a standard. Negative control without extracts was set up in parallel. The result is expressed as percentage inhibition [15].

\section{Calculation}

Inhibition (\%)=Absorption of the control - Absorption of the sample/ Absorption of the control $\times 100$.

\section{$50 \%$ inhibitory concentration (IC50) calculation [16]}

The IC50 of the sample and control calculation $=(\mathrm{AC}-\mathrm{AS}) / \mathrm{AC} \times 100$.

\section{RESULTS}

\section{Alpha-amylase assay}

The maximum inhibitory activity of the sample was $61 \%$ (C. haematocephala) and IC50 at around $82.18 \mu \mathrm{g} / \mathrm{ml}$. Whereas, the maximum inhibitory activity of control (acarbose) was $92 \%$ and IC50 was at around $42.65 \mu \mathrm{g} / \mathrm{ml}$ (Table 1). Then, the graph was plotted with the concentration of sample on X-axis and percentage of inhibition of alpha-amylase enzyme at Y-axis (Fig. 1).

\section{Alpha-glucosidase assay}

The sample showed inhibitory activity of $71 \%$ (C. haematocephala) and IC50 at around $31.07 \mu \mathrm{g} / \mathrm{ml}$. Whereas, the maximum inhibitory activity of control (acarbose) was $89 \%$ and IC50 was at around $62.28 \mu \mathrm{g} / \mathrm{ml}$ (Table 2). Then, the graph was plotted with the concentration of sample on $\mathrm{X}$-axis and percentage inhibition of alpha-glucosidase enzyme at Y-axis (Fig. 2)

Table 1: In vitro antidiabetic activity of $C$. haematocephala by alpha-amylase method and IC50 calculation of both sample and control (acarbose)

\begin{tabular}{lll}
\hline $\begin{array}{l}\text { Concentration of sample } \\
(\boldsymbol{\mu g} / \mathbf{m l})\end{array}$ & $\begin{array}{l}\text { \% inhibition } \\
\text { sample }\end{array}$ & $\begin{array}{l}\text { \% inhibition } \\
\text { of acarbose }\end{array}$ \\
\hline 20 & 15 & 36 \\
40 & 23 & 47 \\
60 & 35 & 59 \\
80 & 50 & 78 \\
100 & 61 & 92 \\
IC50 $(\mu \mathrm{g} / \mathrm{ml})$ & $82.18(\mu \mathrm{g} / \mathrm{ml})$ & $42.65(\mu \mathrm{g} / \mathrm{ml})$ \\
\hline
\end{tabular}

C. haematocephala: Calliandra haematocephala, IC50: Half maximal inhibitory concentration

\section{DISCUSSION}

Postprandial hyperglycemia is the important key factor for glycemic control and predictor of micro- and macro-vascular complications in diabetes mellitus [17]. Drugs which inhibit the alpha-amylase and alpha-glucosidase enzymes and reduce the postprandial hyperglycemia could be a novel approach for this metabolic disorder. These drugs inhibit the conversion of postprandial starch into simple glucose and its intestinal absorption. In addition to it, alpha-

Table 2: In vitro antidiabetic activity of $C$. haematocephala by alpha-glucosidase method and IC50 calculation of both sample and control (acarbose)

\begin{tabular}{lll}
\hline $\begin{array}{l}\text { Concentration of sample } \\
(\boldsymbol{\mu g} / \mathrm{ml})\end{array}$ & $\begin{array}{l}\text { \% inhibition } \\
\text { sample }\end{array}$ & $\begin{array}{l}\text { \% inhibition } \\
\text { of acarbose }\end{array}$ \\
\hline 20 & 29 & 45 \\
40 & 37 & 53 \\
60 & 49 & 67 \\
80 & 58 & 77 \\
100 & 71 & 89 \\
IC50 $(\mu \mathrm{g} / \mathrm{ml})$ & $31.07(\mu \mathrm{g} / \mathrm{ml})$ & $62.28(\mu \mathrm{g} / \mathrm{ml})$ \\
\hline
\end{tabular}

C. haematocephala: Calliandra haematocephala, IC50: Half maximal inhibitory concentration

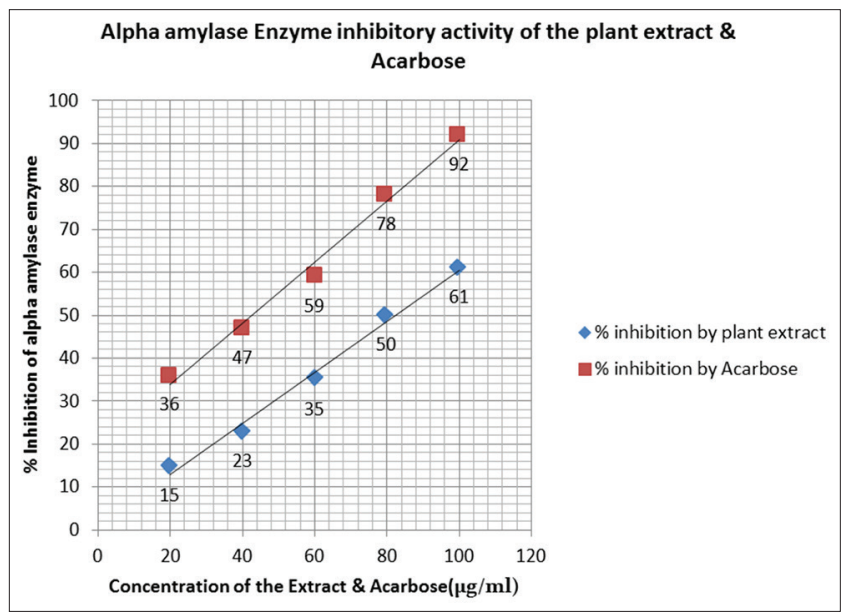

Fig. 1: In vitro antidiabetic activity of Calliandra haematocephala by alpha-amylase method and half maximal inhibitory concentration calculation of both sample and control (acarbose)

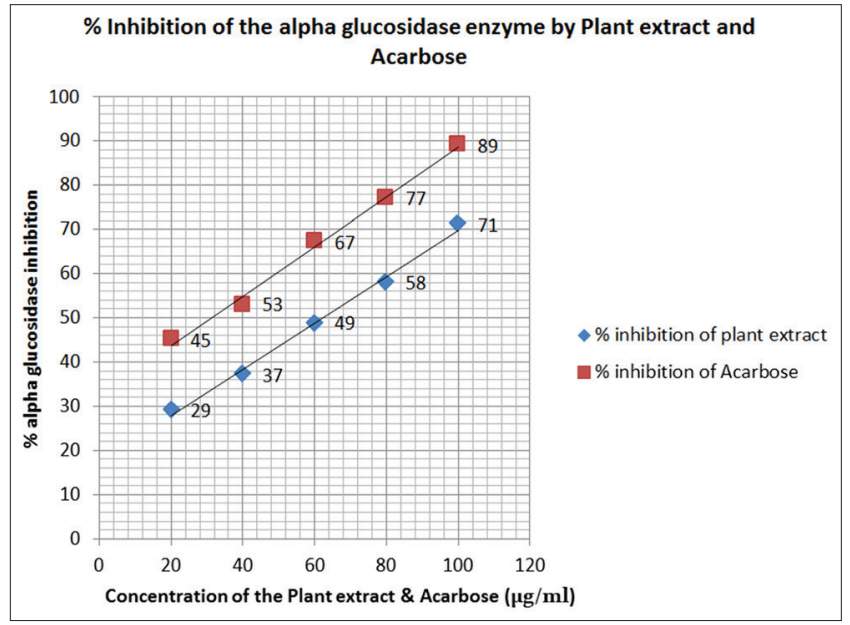

Fig. 2: In vitro antidiabetic activity of Calliandra haematocephala by alpha-glucosidase method and half maximal inhibitory concentration calculation of both sample and control (acarbose) 
glucosidase inhibitors increase the release of the glucoregulatory hormone glucagon-like peptide-1 (GLP-1) into the circulation which contributes the glucose-lowering effect further [18]. Hence, they are effective as GLP-1 analogs and play in major therapeutic intervention of Type 2 diabetes mellitus. Acarbose, miglitol, and voglibose are used in newly diagnosed Type 2 diabetes and as a add-on drug with sulfonylureas and metformin to control the postprandial surge. However, gastrointestinal side effects are more with these synthetic inhibitors [19].

Herbal medicines have been used successfully in managing diabetes because of its ready availability, lesser side effects, and costeffectiveness. Plants are good inhibitors of alpha-amylase and alphaglucosidase and also have insulin-like activity [12]. In diabetes, increased lipid peroxidation leads to significant structural changes and alters lipid metabolism. Chronic hyperglycemia increases the production of reactive oxygen species that leads to the vascular complications through lipid peroxidation [20]. It is established that plant-derived bioactive phytochemicals have antidiabetic potential and reduce hyperglycemia. Hence, plants possess both antioxidant and antidiabetic properties could be a novel approach to prevent diabetic complications [21,22]. Docking studies also proved and isolated the active ingredients from the promising antidiabetic plants [23].

Flavonoids particularly isoquercitrin inhibit the sodium-dependent glucose uptake in the intestinal mucosa through sodium-dependent glucose transporter-1, delay the gastric emptying, stimulating glucose transporter 4 expression in skeletal muscles, and increase insulin sensitivity $[24,25]$. The antioxidant and anti-inflammatory actions of flavonoids protect the blood vessels and prevent the micro- and macro-vascular complications. Myricetin also possesses antioxidant, anti-inflammatory, and ameliorates insulin resistance [26]. One study showed that the leaves and bark of Calliandra surinamensis a different species of Calliandra were assessed for antidiabetic potential and found to be effective [27]. The phytochemical analysis of the C. haematocephala leaves extract shows the presence of alkaloids, tannins, flavonoids, saponin, and glycosides. It is proved that flavonoids, tannins, and glycosides isolated from $C$. haematocephala found to possess greater antioxidant activities [28]. Compounds such as myricetin and quercetin isolated from bark and leaves of $C$. haematocephala are found to possess strong radical scavenging properties [29,30]. Moreover, several studies supported the positive correlation of antioxidant properties with alphaamylase and alpha-glucosidase inhibitory activities [12,13]. Hence, the antioxidant and alpha-amylase and alpha-glucosidase enzyme inhibitory properties ideally support the antihyperglycemic activity of C. haematocephala.

\section{CONCLUSION}

Hence, this study proved the antihyperglycemic activity and antidiabetic potential of $C$. haematocephala in type 2 diabetes mellitus. In comparison to synthetic alpha-glucosidase enzyme inhibitors, this plant could be a better alternative or adjuvant by increasing the efficacy of other antidiabetic drugs. However, isolating the compound which is responsible for the enzyme inhibitory activity would be a better lead and adjuvant in the control of diabetes mellitus.

\section{ACKNOWLEDGMENT}

The authors thank the Faculty - Department of Pharmacology, Sree Ramachandra Medical College and Sree Balaji Medical College, for their support to conduct this study.

\section{AUTHORS' CONTRIBUTION}

Dr. Punnagai K (First author) - Concept, planned the experiments, analyzed the data and graph, and manuscript editing.

Dr. Glory Josephine I (Second and corresponding author) - Planned and conducted the experiments and manuscript writing.

\section{CONFLICTS OF INTEREST}

The authors declare that they have no conflicts of interest.

\section{REFERENCES}

1. WHO. Global Report on Diabetes.Geneva: World Health Organization; 2016.

2. Mathers CD, Loncar D. Projections of global mortality and burden of disease from 2002 to 2030. PLoS Med 2006;3:442.

3. Ramachandran A, Snehalatha C. Current scenario of diabetes in India. J Diabetes 2009;1:18-28.

4. Patel DK, Kumar R, Laloo D, Hemalatha S. Diabetes mellitus: An overview on its pharmacological aspects and reported medicinal plants having antidiabetic activity. Asian Pac J Trop Biomed 2012;2:411-20.

5. Arumugam G, Manjula P, Paari N. A review: Anti diabetic medicinal plants used for diabetes mellitus. J Acute Disease 2013;2013:196-200.

6. Barbosa AP, da Silva PB, Parente JP. Evaluation of gastroprotective activity of Calliandra haematocephala extracts. Planta Med 2012;78:448.

7. Abo-Elhamd AM, Aboul-Enein AM, Mohamed SM. Chemical characterization, antioxidant and antihepatotoxic activities of Calliandra haematocephala (Hassk.), growing in Egypt. J Chem Pharm Res 2016;8:828-45

8. Kasiwada Y, Hashimoto F, Cosentino LM, Chen CH, Garrett PE. Betulinic acid and dihydro betulinic acid derivatives as potent anti HIV agents. J Med Chem 1996;39:1016-7.

9. Shaheen M, Mustafa S, El-Esnawy N. Antirota viral effects of Calliandra haematocephala leaf extracts in-vitro and in-vivo. J Virol Antivir Res 2015;4:1-7.

10. Raja S, Ramesh V, Thivaharan V. Green biosynthesis of silver nanoparticles of Calliandra haematocephala leaf extract, their antibacterial activity and hydrogen peroxide sensing capability. Arab J Chem 2017;10:253-61.

11. Zeid AA, Hiffnawy M, Saleh M, Sleem A, Mohamed R, Hifnawy MS, et al. Flavonoids, volatiles and biological activities of the aerial parts of the Calliandra haematocephala Hassk. Planta Med 2006;72:335.

12. Nair SS, Kavrekar V, Mishra A. In vitro studies on alpha amylase and alpha glucosidase inhibitory activities of selected plant extracts. Eur J Exp Biol 2013;3:128-32.

13. Ramkumar KM, Thayumanavan B, Palvannan T, Rajaguru P. Inhibitory effect of Gymnema montanum leaves on $\alpha$-glucosidase activity and $\alpha$-amylase activity and their relationship with polyphenolic content. Med Chem Res 2010;19:948-61.

14. Rege AA, Chowdhary AS. Evaluation of Alpha amylase and alpha glucosidase inhibitory activity of Rhizophora mucronata. Int J Pharm Sci Res 2014;5:2261-5.

15. Mohamed A, Thirumurugan K. Screening of Fifeen Indian ayurvedic plants for alpha-glucosidase inhibitory activity and enzyme kinetics. Int J Pharm Pharm Sci 2011:3:267-74.

16. Shai LJ, Magano SR, Lebello SL, Mogale AM. Inhibitory effect of five medicinal plants on rat alpha-glucosidase. Comparison with their effects on yeast alpha-glucosidase. J Med Plants Res 2011;5:2863-7.

17. Madsbad S. Impact on postprandial glucose control on diabetes related complications. J Diabetes Complications 2016;30:374-85.

18. Brunton L, Knollman B, Hilal-Dantan R. Endocrine pancreas and pharmacotherapy of diabetes mellitus and hypoglycemia. Goodman and Gilman's the Pharmacological Basis of Therapeutics. 13 $3^{\text {th }}$ ed. New York: McGraw-Hill; 2018.

19. Ibrahim R. Diabetes mellitus Type II: Review of oral treatment options. Int J Pharm Pharm Sci 2010;2:21-30.

20. Ceriello A, Testa R. Antioxidant and anti-inflammatory treatment in Type 2 diabetes. Diabetes Care 2009;32:5232-6.

21. Singh S, Garg V, Yadav D. Antihyperglycemic and antioxidative ability of Stevia rebaudiana (Bertoni). Leaves in diabetes induced mice. Int J Pharm Pharm Sci 2013:5:297-302

22. Misbah H, Aziz AA, Aminudin N. Author information anti-diabetic and anti-oxidant peoperties of Fiscus deltoidea fruit extracts and fractions. BMC Compliment Altern Med 2013;13:118.

23. Saravanamuttu S, Sudarsanam D. Antidiabetic plants and their active ingredients: A review. Int J Pharm Sci Res 2012;3:3639-50.

24. Ndong M, Uehara M, Katsumata S, Suzuki K. Effects of oral administration of Moringa aleifera Lam on glucose tolerance in Gotokakizaki and wistar rats. J Clin Biochem Nutr 2007;40:229-33.

25. Cermak R, Landgraf S, Wolffram S. Quercetin glycosides inhibit glucose uptake into brush-border membrane vesicles of porcine Jejunum. Br J Nutr 2004;91:849-55. 
26. Saritha M. Flavanoids-the most potent polyphenols as as antidiabetic agents: An overview. Mod Appro Drug Des 2017;1:1-5.

27. Abdullah A, Abbott G, Young LC, John I, Gray AI, Valerie F. Phytochemical and biological investigation of Calliandra surinamensis as a potential treatment for diabetes. Planta Med 2016;81:S1-381.

28. Wei S, Chen H, Lin Y. Comparison of chemical compositions and antioxidant activities of condensed tannins from different parts of
Calliandra haematocephala. J Wood Chem Technol 2015;35:193-206.

29. Gupta R, Garg A, Sharma P, Pandey P. Wound healing and antioxidant effect of Calliandra haematocephala leaves on incision and excision wound models. Asian J Pharm Pharmacol 2016;2:34-9.

30. Moharram FA, Marzouk MS, Ibrahim MT, Mabry TJ. Antioxidant galloylated flavonol glycosides from Calliandra haematocephala. Natl Prod Res 2006;20:927-34. 